\title{
The Right to Record and Broadcast Public Legislative Proceedings
}

Most legislative bodies in the United States hold their proceedings open to attendance by the public. ${ }^{1}$ When they do, the first amendment protects the right of the press ${ }^{2}$ to attend the proceedings and to report about them to the public. ${ }^{3}$ Many legislatures, however, enforce rules that prohibit reporters from broadcasting their proceedings or from recording them by any means other than handwritten notes. ${ }^{4}$ This comment suggests that the first amendment protects not only the right of the press to attend public legislative proceedings, but also its right to record and broadcast them. The comment begins by analyzing first amendment protections in terms of the entire process of reporting news, focusing on the press's right to gather news by attending public events and recording information concerning the events by a variety of

1. Many are required to do so by statute. See generally Wickham, Let the Sun Shine In! Open-Meeting Legislation Can Be Our Key to Closed Doors in State and Local Government, 68 Nw. U.L. REv. 480 (1973) (open-meeting statutes of thirty-five states are surveyed). Such statutes usually provide for closed meetings under specified circumstances. Id. at 483-87. Although both houses of Congress and many state legislatures have the authority to vote to hold closed sessions, they rarely do. H. Cross, The People's Right to Know 182-92 (1954); F. Thayer, Legal Control of The Press 33-40 (1956).

An argument might be made that protection of the freedom of the press would require a high burden of justification for denying access to any legislative proceeding, but this comment will be concerned only with the constitutionality of restricting certain methods of recording once physical access is authorized. Cf. note 27 infra.

2. The press protected by the first amendment is broadly defined to include "in its historic connotation ... every sort of publication which affords a vehicle of information and opinion." Lovell v. City of Griffin, 303 U.S. 444, 452 (1938). Media that have been held entitled to this first amendment protection, beyond the books, newspapers, and handbills familiar to the amendment's authors, include motion pictures, Joseph Burstyn, Inc. v. Wilson, 343 U.S. 495, 501-02 (1952), radio, United States v. Paramount Pictures, Inc., 334 U.S. 131, 166 (1948) (dictum), and television, Estes v. Texas, 381 U.S. 532, 539 (1965) (dictum); Robinson v. American Broadcasting Co., 44I F.2d 1396, 1400-01 (6th Cir. 1971).

3. See Pennekamp v. Florida, 328 U.S. 331 (1946); Bridges v. California, 314 U.S. 252 (1941).

4. Neither house of Congress permits electronic recording or broadcasting of floor sessions, although congressional committees are authorized to allow them. See notes 123, 127, 128 infra. One or both houses of thirteen state legislatures have rules banning live radio or television broadcasts from their chambers. Of these, two allow taping privileges. In several of the other states, approval by legislative membership or officers is required. Hearings on Congress and Mass Communications Before the Joint Comm. on Congressional Operations, 93d Cong., 2d Sess. App. 949-50 (1974) [hereinafter cited as 1974 Hearings]. 
methods. It then identifies and examines the restriction of first amendment rights produced by prohibiting the tape recording ${ }^{5}$ or broadcasting of open legislative proceedings. Finally, the comment evaluates arguments that recording or broadcasting would be detrimental to legislative proceedings and that rules less restrictive than complete bans would not prevent the potential harm, and concludes that they are insufficient to justify the restriction of the freedom of the press.

\section{The First Amendment Right of the Press to Record Public Events}

\section{A. The Reporting Process and the First Amendment}

The process of reporting events to the public may be divided analytically into several successive steps. First, a representative of the press medium must physically attend the event ${ }^{6}$ and record information about it. After organizing the recorded information into appropriate form (a "report"), the medium disseminates it generally so that members of the public finally receive the information that has been gathered. Each step of the reporting process necessarily depends upon the performance of the previous steps, and restraint on the press at any step thus restricts its ability to perform its ultimate function of informing the public. Because a basic purpose of the first amendment is to foster a free flow of information concerning public affairs to the people-the ultimate decision makers and source of governmental power in a democratic society ${ }^{7}$ - the courts have developed first amendment protections for the entire reporting process. The right of the public to receive information is closely guarded, ${ }^{8}$ even in rare instances in which the party seeking to communicate the information lacks the right to disseminate it. ${ }^{9}$ Prior restraint by the government on dis-

5. Throughout this comment, tape recording will be used to refer to both audio and video tape recording.

6. The representative need not be formally affiliated with the medium, but physical attendance by some cooperating observer is necessary in any case.

7. See, e.g., Cox Broadcasting Corp. x. Cohn, 95 S. Ct. 1029, 1044, 1046 (1975); Rosenbloom v. Metromedia, Inc., 403 U.S. 29, 41-42 (1971): Grosjean r. American Press, 297 U.S. 233, 230 (1936): Saxbe v. Washington Post Co., 94 S. Ct. 281 I, $2821-22$ (1974) (Powell, J., dissenting): T. Emerson, Toward a General Theory of The First Amendment 7-15 (1966) Meiklejohn, The Fïst Amendment is an Absolute, 1961 Sup. CT. Rev. 245, 255.

8. Stanley v. Georgia, 394 U.S. 557, 564 (1969), and authorities cited therein.

9. See, e.g., Procunier v. Martinez, 416 U.S. 396, 408-09 (1974) (right to receive mail from prisoners); Kleindienst v. Mandel, 408 U.S. 753, 762-65 (1972) (dictum) (right of citizen to hear views of alien); Virginia Citizens Consumer Council, Inc. v. State Bd. of 
semination of information by the press is all but completely prohibited, ${ }^{10}$ and the Supreme Court has held that the first amendment also prohibits the government from requiring the press to publish particular material. ${ }^{11}$

Protecting the right of members of the press to perform the very first steps of the reporting process-attending and recording public events-is no less essential in guaranteeing a free flow of information to the public. This prerequisite "right to gather news"12 has been recognized by the Supreme Court, but has been given limited scope in recent cases. In Branzburg $v$. Hayes, ${ }^{13}$ newsmen asserted a privilege against revealing confidential news sources to a grand jury, arguing that their ability to gather news from such sources would be impaired if they were forced to reveal the identity of those sources. ${ }^{14}$ Although the Court stated that "news gathering is not without its First Amendment protections"15 and that "without some protection for seeking out the news, freedom of the press could be eviscerated,"16 the five-member majority concluded that the "consequential, but uncertain" burden on news gathering that resulted from forcing reporters to testify was outweighed by more direct public interests in law enforcement and in effective grand

Pharmacy, 373 F. Supp. $683,685-87$ (E.D. Va. 1974), prob. juris. noted, $\overline{9} 5$ S. Ct. $13 \overline{8} 9$ (1975) (right of consumer to receive drug price advertisements).

10. See, e.g., New York Times Co. v. United States, 403 U.S. 713, 714 (1971); Near v. Minnesota ex rel. Olson, 283 U.S. 697, 713-19 (1931).

11. Miami Herald Publishing Co. v. Tornillo, 418 U.S. 24I, 256-58 (1974). The integrity of the editorial step of the reporting process, in which the information gathered is organized into the form in which it is to be disseminated, is implicitly guaranteed by the correlative prohibitions against prior restraints and compulsory publication. See id.

Knotty problems remain, however, in defining the extent of these first amendment protections for the broadcast media in contrast with the print media. Some degree of control by the FCC over broadcast content is justified on the theory that broadcast licensees, as holders of temporary monopolies of scarce public resources, cannot be permitted to air only their own views. Accordingly, the FCC has developed the Fairness Doctrine and right to reply rules. See Columbia Broadcasting Sys., Inc. v. Democratic Nat'l Comm., 412 U.S. 94, 101-02 (1973); Red Lion Broadcasting Co. v. FCC, 395 U.S. 367, 389-90 (1969). The Supreme Court, in evaluating FCC regulation in Columbia Broadcasting, recognized the necessity of balancing the broadcasters' first amendment interests in performing the editorial function against the public's first amendment interest in receiving diverse views. 412 U.S. 94, 102 (1973). But apart from justifiable FCC regulation, broadcasters may assert first amendment rights against prior restraints on their broadcasts. Robinson v. American Broadcasting Co., 441 F.2d 1396, 1401 (6th Cir. 1971).

12. See generally Comment, The Rights of the Public and the Press to Gather Information, 87 Harv. L. Rev. 1505 (1974); Note, The Right of the Press to Gather Information, 71 Colum. L. REv. 838 (1971).

13. 408 U.S. 665 (1972).

14. Id. at $679-80$.

15. Id. at 707.

16. Id. at 681 . 
jury proceedings. ${ }^{17}$ The Court stated as well that it found no basis for a "constitutional right of special access to information not available to the public generally." 18

In Pell v. Procunier, ${ }^{19}$ a similarly divided Court held that prison rules prohibiting reporters from conducting face-to-face interviews with selected inmates violated neither the inmates'20 nor the reporters $^{21}$ first amendment rights. ${ }^{22}$ After considering both the importance of the government's interest in restricting access to the prison in order to maintain prison discipline and the availability of alternative means by which reporters could obtain information about prisons, ${ }^{23}$ the Court held that "the Constitution

17. Id. at 690-91. Justice Powell filed a separate concurrence "to emphasize what seems to me to be the limited nature of the Court's holding. The Court does not hold that newsmen ... are without constitutional rights with respect to the gathering of news or in safeguarding their sources." Id. at 709; $c f$. note 22 infra.

18. 408 U.S. at 684 . The Branzburg Court relied on Zemel v. Rusk, 381 U.S. 1 (1965), in which a private citizen (not a newsman) had contended that the Secretary of State's statutorily authorized refusal to validate his passport for travel to Cuba abridged his first amendment right to gather information about the Cuban government. Id. at 16. Conceding that the Secretary's refusal "renders less than wholly free the flow of information" about Cuba, id., the Zemel Court held that the restriction was on rights of action rather than speech, and hence could not be violative of the first amendment. The Branzburg Court quoted the following portion of Zemel:

There are few restrictions on action which could not be clothed by ingenious argument in the garb of decreased data flow. For example, the prohibition of unauthorized entry into the White House diminishes the citizen's opportunities to gather information ... but that does not make entry into the White House a First Amendment right. The right to speak and publish does not carry with it the unrestrained right to gather information. 408 U.S. at 684 \& n.22 (1972), quoting Zemel v. Rusk, 381 U.S. 1, 16-17 (1965).

On the same day it decided Branzburg, however, the Court gave more limited application to the same language in Zemel by rejecting the government's argument in Kleindienst v. Mandel, 408 U.S. 753 (1972), that the refusal to permit a foreign scholar to enter the United States was merely a restriction on action and not on first amendment rights. Id. at 764 . Although the Court found that the government's refusal was justified by the overriding power of Congress to control the admission of aliens, it recognized that in absence of that power, a first amendment claim of a right to hear the scholar might properly be raised by those who sought his entry. Id. at 765. See Note, The Right of the Press to Gather Information, 71 Colum. L. Rev. 838, 845-46 (1971).

19. 94 S. Ct. 2800 (1974). Pell was heard and decided with its companion case Saxbe v. Washington Post Co., 94 S. Ct. 2811 (1974), which considered an identical prohibition of interviews at a federal prison.

20. 94 S. Ct. at 2807.

21. Id. at 2810 .

22. Justice Powell, concurring in the Court's holding against the prisoners in Pell but dissenting from its holding that the reporters' right to gather news was not violated, had written a concurring opinion against the newsmen's claim in Branzburg. See note 17 supra. Justice Stewart, who had dissented in Branzburg while complaining of "[t]he Court's crabbed view of the First Amendment," 408 U.S. at 725, joined the majority against the newsmen's claim in Pell and Saxbe and wrote the opinion of the Court. Cf. Estes v. Texas, 381 U.S. 532, 614-15 (1965) (Stewart, J., dissenting); note 33 infra.

23. 94 S. Ct. 2800, 2804-06, 2808 (1974). 
[does not impose] upon government the affirmative duty to make available to journalists sources of information not available to members of the public generally." 24

Both Branzburg and Pell involved reporters' claims that their access to news sources was protected under a first amendment right to gather news. The Court in both cases considered that right to be subject to limitations justified by important conflicting societal interests but held only that no such justification need be shown where the physical access sought by the press is broader than that accorded to the general public. ${ }^{25}$ Thus, the Court focused on defining the scope of "public" events and information to which the press has a right of physical access, without investigating the justifications for denying access to the public itself beyond noting the importance of the government's interests in grand jury effectiveness and prison control. ${ }^{26}$ In neither case did the Court determine the extent to which the right of the press to record information must be protected once physical access to a news source, or attendance at a newsworthy event, is authorized. ${ }^{27}$ Resolving that

24. Id. at 2810 .

25. See id.; Branzburg v. Hayes, 408 U.S. 665, 684 (1972). The Court stated in Pell's "constitutionally indistinguishable" companion case that "it is unnecessary to engage in any delicate balancing of ... penal considerations against the legitimate demands of the First Amendment. For it is apparent that the sole limitation imposed on newsgathering . . . is justified by ... 'the truism that prisons are institutions where public access is generally limited.' "Saxbe v. Washington Post Co., 94 S. Ct. 2811, 2814, 2815 (1974). Cf. Cox Broadcasting Corp. v. Cohn, 95 S. Ct. 1029, 1047 (1975) (holding that once records are made public, the right of the press to disseminate information may not be overridden by a claim of a right to privacy).

Courts have, however, also recognized the first amendment news gathering right of members of the press to obtain access at least equal to that expressly granted by the government to other members of the press, even if the public has no right to such access. See, e.g., Borrecca v. Fasi, 369 F. Supp. 906, 909 (D. Hawaii 1974) (access to mayor's press conferences); Lewis v. Baxley, 368 F. Supp. 768, $775-77$ (M.D. Ala. 1973) (access to state legislative press galleries); Consumers Union of United States, Inc. v. Periodical Correspondents' Ass'n, 365 F. Supp. 18, 25-27 (D.D.C. 1973) (access to congressional press galleries); Quad-City Community News Serv., Inc. v. Jebens, 334 F. Supp. 8, 13-14 (S.D. Iowa 1971) (access to police files).

26. See Branzburg v. Hayes, 408 U.S. 665, 690-91 (1972); Pell v. Procunier, 94 S. Ct. 2800, 2808-09 (1974). Defining the exact limits of the right of access enjoyed by the public, or the scope of public events and information, is a difficult task in itself. See Comment, The Rights of the Public and the Press to Gather Information, 87 HARv. L. Rev. 1505, 1507 (1974).

27. Justice Powell, dissenting in Pell and Saxbe, argued that the press must have greater access than the public in order to perform its first amendment function of providing the public with the information necessary for intelligent self-government. Saxbe v. Washington Post Co., 94 S. Ct. 2811, 2821-22 (1974) (Powell, J., dissenting). After considering the asserted governmental interests in limiting access, weighed against this important first amendment right of the press, Justice Powell concluded that no absolute prohibition of face-to-face interviews with selected prisoners could be justified. Id. at 2823-25. He specifi- 
issue requires the consideration of conflicting interests in protecting the right to gather news and in preventing interference with governmental functions. ${ }^{28}$

\section{B. Limits on the Right of the Press to Record Public Proceedings}

The Supreme Court has considered the issue of the press's right to record public proceedings only once. In Estes $v$. Texas, ${ }^{29}$ the Court held that a criminal defendant was denied due process because portions of his trial were filmed and telecast. ${ }^{30}$ The point on which the Court focused its attention ${ }^{31}$ was whether the defendant should be required to show actual prejudice or whether prejudice should be presumed from the fact of televising. ${ }^{32}$ To reach its result, however, the Court was required to consider as well the argument presented by broadcasters' organizations as amici curiae that to prevent courtroom filming and telecasting would infringe broadcasters' first amendment rights. ${ }^{33}$ The broadcasters argued

cally refrained from addressing the further question of whether the right to record information with television equipment could justifiably be curtailed even if press access to the prison was constitutionally protected. $I d$. at 2815 n.l.

28. To subject the press's right to record to the test of coextensivity with the rights of the public, which Branzburg and Pell applied in considering the right of physical access, would be to vitiate the right of the press to gather news altogether. Although it may be appropriate to allow reporters access only to public information and events, their right to record information must be broader than that of the public if they are to make effective use of such access in performing the first amendment function of the press.

29. 381 U.S. 532 (1965).

30. Id. at 535. Estes marked the climax of thirty years of debate over the question of broadcasting trials. After the radio broadcast of Bruno Hauptman's trial for the Lindbergh kidnapping, see State v. Hauptman, 115 N.J.L. 412, 180 A. 809 (Ct. Err. \& App.), cert. dened, 296 U.S. 649 (1935), the American Bar Association adopted Canon 35 of the Canons of Judicial Ethics (superseded by Canon 3.A(7) of the $A B A$ Code of Judicial Conduct) forbidding photography or broadcasting in courtrooms. The history of Canon $3 \mathbf{5}$ is outlined in an appendix to the opinion of Justice Harlan in Estes $v$. Texas, 381 U.S. 532, 596 (1965). At the time of the trial in the Estes case, forty-eight states and the federal courts did not permit broadcasting from the courtroom, a fact which the Court found "most telling" in reaching its conclusion. Id. at 540 . Colorado, after hearings conducted by a state supreme court justice, In re Canon 35 of the Canons of Judicial Ethics, 132 Colo. 591, 296 P.2d 465 (1956), had decided to leave broadcasting to the trial judge's discretion. For a review of the competing viewpoints, arguments, and decisions before Estes, see Comment, Constitutional Aspects of Television in the Courtroom, 35 U. CIN. L. REv. 48 (1966).

31. The opinion of the Court by Justice Clark devoted twelve pages to the due process question and less than one page to the first amendment issue; three pages of Chief Justice Warren's thirty-four page concurrence (joined by Justices Douglas and Goldberg) treated the first amendment question.

32. See 381 U.S. at 542-44 (opinion of the Court); id. at 601-02 (Stewart, J., dissenting).

33. Justice Stewart was technically correct to point out in dissent that "no First Amendment claim is made in this case," id. at 614 , since the issue was whether defendant had 
that recording is a right protected by the first amendment, and that to permit newspaper reporters to take handwritten notes in the courtroom during a criminal trial while forbidding broadcast reporters from recording electronically would discriminate unfairly between the two media. ${ }^{34}$

The Court answered the discrimination argument, and at the same time reemphasized the determinative factor in the case, by noting that television and radio reporters were subject to the identical restriction as newspaper reporters and all other members of the public-that the activities of those in attendance must not jeopardize the defendant's right to a fair trial. ${ }^{35}$ The majority stated that whatever the rights of the press to record might be outside the courtroom, ${ }^{36}$ inside it those rights were subordinate to the preservation of a fair trial, "the most fundamental of all freedoms." 37 While reaffirming its decisions that trial courts cannot prevent reporters from attending public trials and subsequently publishing even prejudicial reports outside the courtroom, ${ }^{38}$ the Court held that insofar as press coverage inside the courtroom -apart from the mere presence of the reporters-might affect the course of a trial, it must be controlled. ${ }^{39}$

Turning then to an evaluation of the impact of broadcasting on the defendant's right to a fair trial, ${ }^{40}$ the Estes Court identified

received a fair trial. He stated further, however, that " $[t]$ he suggestion that there are limits upon the public's right to know what goes on in the courtroom causes me great concern. The idea of imposing upon any medium of communications the burden of justifying its presence is contrary to where I had always thought the presumption must lie in the area of First Amendment freedoms." Id. at 614-15. In view of the concern with the press's right to gather news expressed by Justice Stewart in Estes and in Branzburg, see 408 U.S. at 725-28, his contrary vote and opinion in Pell mark a dramatic change of position. See note 22 supra.

34. Brief for Nat'l Ass'n of Broadcasters and the Radio Television News Directors Ass'n as Amici Curiae at 7-12. See Estes v. Texas, 381 U.S. 532, 539 (1965).

35. 381 U.S. at 539-40. Of the majority, only Justice Harlan met the discrimination argument head on, admitting that telecasting trials "might well provide the most accurate and comprehensive means" of reporting trials. He concluded, however, that such considerations "are not arguments of constitutional proportions." 381 U.S. at 589 (Harlan, J., concurring).

36. Chief Justice Warren admitted that "the television industry . . . has a proper area of activities and limitations beyond which it cannot go with its cameras. That area does not extend into an American courtroom." Id. at 585. Justice Harlan agreed, saying "the line is drawn at the courthouse door; within, a reporter's constitutional rights are no greater than those of any other member of the public." Id. at 589.

37. Id. at 540. See id. at 589 (Harlan, J., concurring).

38. Id. at 541-42, citing Bridges v. California, 314 U.S. 252 (1941), and Pennekamp v. Florida, 328 U.S. 331 (1946).

39. Id. at 539-40 (1965).

40. See generally Sheppard v. Maxwell, 384 U.S. 333 (1966); Rideau v. Louisiana, 373 U.S. 723 (1963); Irwin v. Dowd, 366 U.S. 717 (1961); American Bar Association, Project 
three different kinds of potentially prejudicial effects: increased trial publicity, physical disruption of proceedings, and psychological distraction of trial participants. The majority thought that the first, increased publicity, could affect a trial in a variety of ways: jurors might observe delayed telecasts of trials still in progress, ${ }^{41}$ the rule excluding witnesses from the courtroom during the testimony of others would become virtually impossible to enforce, trial participants would be more readily recognized and accosted in public during the trial, and unbiased jurors for new trials would become more difficult to find. ${ }^{42}$ Even though the Court had previously held that the first amendment protects the press's basic right to attend and report about trials ${ }^{43}$ as part of the right to publish news, the majority recognized the power of a trial court to limit publicity under rules governing the one physical area in which the defendant's rights are of overriding concern, the courtroom itself. ${ }^{44}$

on Minmum Standards for Criminal Justice, Standards Relating to Fair Trial and Free Press ("Reardon Report") (1966); D. Gillmor, Free Press and Fair Trial (1966); Symposium 1967, 42 Notre DaMe Law. 857 (1967).

41. This was not a danger in Estes itself because the jury had been sequestered throughout the trial. 381 U.S. at 546.

42. Id. at 546-57. The Court emphasized that the sixth amendment requires a trial to be public solely to protect the defendant from "star chamber" proceedings, id. at 538-39; see id. at 583-84 (Warren, C.J., concurring); id. at 588 (Harlan, J., concurring), and not to educate or entertain the public. See id. at 575-76 (Warren, C.J., concurring). The Court thought that the amendment's protective function was satisfactorily served by the number of persons who could physically attend court sessions and that it would not be furthered by telecasts of trials. See id. at 584 (Warren, C.J., concurring); id. at 588-89 (Harlan, J., concurring). The sixth amendment, then, was seen as granting no independent right to the public to observe trials either in person or by television. But cf. Lewis v. Peyton, 352 F.2d 791, 792 (4th Cir. 1965) (dictum that the public has interest in open trials in order to prevent prejudice in favor of, as well as against, defendants). The Supreme Court has said that a defendant "has no absolute right to compel a private trial." Singer v. United States, 380 U.S. 24, 35 (1965) (dictum). In Estes, however, the Court sought to insure that public trials would not become more public than necessary, when their fairness was endangered.

43. See, e.g., Craig v. Harney, 331 U.S. 367 (1947); Pennekamp v. Florida, 328 U.S. 331 (1946); Bridges v. California, 314 U.S. 252 (1941).

44. This power was reemphasized in Sheppard v. Maxwell, 384 U.S. 333 (1966), where defendant's conviction was reversed for prejudicial publicity and the "carnival atmosphere" in the courtroom at trial. Id. at 358. The Court said that the trial court's error was

compounded by its holding that it lacked power to control the publicity about the trial. ...

... As we stressed in Estes, the presence of the press must be limited when it is apparent that the accused might otherwise be prejudiced or disadiantaged. Bearing in mind the massive pretrial publicity, the judge should have adopted stricter rules governing the use of the courtroom by newsmen....

Id. at 357-58 (footnotes omitted). The exercise of the trial court's power through "gag orders" arguably raises serious first amendment questions apart from the issue of the freedom of the press. See generally Warren \& Abell, Free Press-Fair Trial: The "Gag Order," A 
The weight to be given to the second potentially prejudicial effect of broadcasting, physical disruption by equipment and personnel, is left uncertain by Estes. Only four members of the majority thought that the record from the pretrial hearing, where physical disruption was quite apparent, ${ }^{45}$ was properly before the Court; ${ }^{46}$ at the trial itself physical disruption was virtually nonexistent. ${ }^{47}$ The majority was more concerned with the third effect, trial participants' psychological reactions to knowledge that they were being televised. ${ }^{48}$ The Court thought that nervousness resulting from lack of television experience would be especially distracting to jurors and witnesses ${ }^{49}$ and that attorneys and judges might be tempted to play for the television audience's attention. ${ }^{50}$ Neither effect could contribute to the fair determination of guilt or innocence, and the Court thought them likely to impede that process. ${ }^{51}$

California Aberration, 45 S. Cai. L. Rev. 51 (1972); Note, Silence Orders, 6 Harv. Giv. Rights-Civ. Lib. L. Rev. 595 (1971). But see United States v. Tijerina, 412 F.2d 661 (10th Cir.), cert. denied, 396 U.S. 990 (1969) (affirming contempt conviction of criminal defendants for violating silence order); Chicago Council of Lawyers v. Bauer, 371 F. Supp. 689 (N.D. Ill. 1974) (refusing to enjoin silence orders imposed on criminal counsel).

45. 381 U.S. at 535-36; see id. at 586 (App. to Opinion of Warren, C.J., concurring, Photographs nos. 1-6).

46. Justice Harlan thought that only the trial record was properly before the Court, $i d$. at 588 (Harlan, J., concurring), as did the four dissenters. Id. at 609-10 (Stewart, J., dissenting).

47. Broadcast reporters were confined to a camouflaged booth at the rear of the courtroom. Id. at 537; see id. at 586 (App. to Opinion of Warren, C.J., concurring, Photograph no. 7).

48. " $[T]$ he evil of televised trials . . . lies not in the noise and appearance of the cameras, but in the trial participants' awareness that they are being televised." Id. at 570 (Warren, C.J., concurring); see id. at $\mathbf{5 4 6 .}$

49. Id. at 545-47.

50. Id. at 548; see id. at 565, 578-79 (Warren, C.J., concurring). The Court admitted that "some of these dangers . . . are present as well in newspaper coverage of any important trial," $i l$. at 548 , but suggested that the difference in the degree of the danger produced by telecasting justified a tighter restriction.

51. Many judges and commentators have expressed the contrary view, based on their experiences, that telecasting trials has no deleterious effects. One judge, for example, has described the televised trial of a defendant accused of dynamiting an airplane in flight, concluding that there was no evidence of any distraction of the trial participants from the "essential dignity of the proceedings." Hall, Colorado's Six Years' Experience Without Canon 35, 48 A.B.A.J. 1120,1121 (1962). A survey of members of the bar who participated in or observed a televised trial in Texas found that "the fact that the trial was being televised seemed to dignify the proceedings" and that "none of the participants expressed any objection to televising future trials in the same manner. Generally, the response was that they would favor it." Waco-McLennon County Bar Ass'n, Courtroom Telerision, 19 TExas B.J. 73, 108 (1956). See also, e.g., In re Canon 35 of the Canons of Judicial Ethics, 132 Colo. 591, 296 P.2d 456 (1956); Lyles 1. State, 330 P.2d 734, $742-45$ (Okla. Crim. App. 1958); In re Mack, 386 Pa. 251, 274, 126 A.2d 679, 687 (1956) (Musmanno, J., dissenting); Quiat, The Freedom of Pressure and the Explosive Canon 35, 33 Rocky Mr. L. Rev. 11 (1960); Wright, A Judge's View: The News Media and Criminal Justice, 50 A.B.A.J. 1125, 1126-27 (1964). 
Although the majority in Estes was primarily concerned with the prejudicial effects of recording and broadcasting on the trial itself and not with the separate issue of the extent of the press's right to record information at a public proceeding, the implications of the decision go further. For where there is a strong probability of prejudice to the fairness of a trial, the right to record is capable of being limited within the physical boundaries of the courtroom. The majority's opinions indicate, however, that where the threat of prejudice is less than that found in Estes, or in areas outside the criminal courtroom, the first amendment right to record and broadcast could not be so easily restricted.52 The extent to which that right will be protected in circumstances other than those present in Estes is suggested by several recent cases.

The reporter's right to record both by memory and by pencil and paper in the courtroom was vindicated in United States $v$. Columbia Broadcasting System, Inc. ${ }^{53}$ in which the Fifth Circuit overturned district court orders that forbade network artists either to sketch pictures of a criminal trial inside the courtroom or to broadcast sketches made from memory outside the courtroom. ${ }^{54}$ Rejecting the government's argument that the dangers of prejudice presumed in Estes justified the orders, the court ruled that in the absence of a showing of actual disruption or distraction, a ban on sketching violated the network's constitutional right to gather news. ${ }^{55}$ In support of its conclusion, the court cited Dorfman $v$.

52. See note 36 supra. The opinion of the Court concludes:

It is said that the ever-advancing techniques of public communication and the adjustment of the public to its presence may bring about a change in the effect of telecasting upon the fairness of trials. But we are not dealing here with future developments in the field of electronics. Our judgment cannot be rested on the hypothesis of tomorrow but must take the facts as they are presented today.

Estes x. Texas, 381 U.S. $532,551-52$ (1965).

53. 497 F.2d 102 (5th Cir. 1974).

54. Id. at 103 .

55. Id. at 106-07. The Fifth Circuit, noting that no other court had sought to ban courtroom sketching, found the district court's rules "overly broad and thus invalid." Id.

Nearly the identical issue had been presented in Wrather-Alsarez Broadcasting, Inc. v. Hewicker, 147 Cal. App. 2d 509, 305 P.2d 236 (Dist. Ct. App. 1957), where a television reporter sued to compel a trial judge to allow the reporter's shorthand secretary to take notes in the judge's criminal courtroom. Id. at 511,305 P.2d at 237 . The judge argued that transcripts of the court reporter's notes were available and that his power to control courtroom conduct had been properly invoked. Id. But the appellate court, considering the order a prior restraint, $i d$. at $512,305 \mathrm{P} .2 \mathrm{~d}$ at 238 , noted that no evidence of disturbance had been presented and concluded that the plaintiff was entitled "at any public hearing in the court where he is rightfully in attendance to take such notes as he may desire concerning the proceedings in any form selected by him so long as it does not interfere with the orderly conduct of the proceedings...." Id. at 514,305 P.2d at 239 . 
Meiszner, ${ }^{56}$ another sequel to Estes. In Dorfman, press representatives sought to enjoin a district court rule that prohibited photography and broadcasting in connection with any judicial proceeding on twelve floors of a twenty-seven floor federal courthouse and office building, including the large ground-floor lobby and an open plaza outside. ${ }^{57}$ The Seventh Circuit invalidated the rule as overbroad insofar as it applied to areas other than floors on which courtrooms were located. ${ }^{58}$ Although it conceded that some potential for prejudice might result from allowing photography in the areas from which it was lifting the ban, the court held that any such "prior restraint on the press" must be justified by an "immediate threat to the judicial proceedings." 59

The press's right to record public events not connected with criminal trials was upheld in Schnell $v$. City of Chicago ${ }^{60}$ and Channel 10, Inc. v. Gunnarson. ${ }^{61}$ In Schnell, a case arising from press attempts to cover street demonstrations during the 1968 Democratic National Convention, the Seventh Circuit reversed the dismissal of a complaint filed by news photographers alleging that police officers had violated their "constitutional right to gather and report news, and to photograph news events." ${ }^{2}$ In Channel 10 the court held that a television cameraman's right to gather news had been infringed by police interference with his cameras while he was filming an arrest in public. ${ }^{63}$ The court ordered that the police refrain from disturbing the cameraman or his equipment unless he was actually "interfering with or endangering them in their work." 64

Viewed in the light of the Columbia Broadcasting, Dorfman, Schnell, and Channel 10 cases, the limits of the Estes holding become apparent. These cases together establish that the right to gather news

56. 430 F.2d 558 (7th Cir. 1970).

57. Id. at 560-61.

58. Id. at 562. The court thought that the ban was proper in the areas inmediately surrounding the first-floor elevators as well. $I d$.

59. Id. at 563 .

60. 407 F.2d 1084 (7th Cir. 1969).

61. 337 F. Supp. 634 (D. Minn. 1972).

62. 407 F.2d at 1085.

63. 337 F. Supp. at $635-36$.

64. I $/$. at 638 . The police claimed that they had seized the camera because Minnesota law forbids release of identities of jureniles who are arrested, and that they did not know at the time whether the arrestees were juveniles; in fact, they were not. $I d$. at 636.

The Chumnel 10 court cited Gazette Publishing Co. v. Cox, Cause No. IP 65-C-528 (S.D. Ind., May 2, 1967), an apparently similar case in which it was held that a publisher and its employees had a constitutional right "to have access to and to make use of the public streets, roads and highways ... f for the purpose of observing and recording in writing and photographically the events which occur there." 337 F. Supp. at 636. 
includes the right to record as well as to attend news events occurring in public. Columbia Broadcasting and Dorfman demonstrate that the presumption of trial prejudice that justified the restriction of press recording rights in Estes is valid only for certain recording methods and only within the confines of the courthouse; beyond these limits a showing of actual prejudice to the criminal trial is required. ${ }^{65}$ Channel 10 and Schnell hold further that outside the trial context, actual interference with proper governmental functions $^{66}$ must be shown before the right to record, even by television cameras, may be restricted.

The substantiality of the interference with governmental processes that must be shown to justify restrictions on the right of the press to record and broadcast depends upon the extent to which these restrictions infringe upon interests protected by the first amendment. Outside the area of criminal trials, in which Estes established a presumption of prejudice that would justify prohibitions against recording and broadcasting, it is important to ascertain the first amendment interests implicated and the weight to be given them in the final balancing.

\section{Restriction of the First Amendment Right to Record and Broadcast Public Legislative Proceedings}

Rules that limit the use of certain methods of recording public legislative proceedings impinge upon protected first amendment interests of the press, and upon inextricable interests of the public, when they impede the free flow of information about the proceed-

65. The presumption that a criminal defendant cannot receive a fair trial in the presence of courtroom photography has also been sharply limited in other cases. See, e.g., Bradley v. Texas, 470 F.2d 785, 787-88 (5th Cir. 1972) (affirming conviction over defendant's claim that still and motion picture photography at his trial violated due process, apparently finding a distinction between motion picture and television cameras); Bell v. Patterson, $279 \mathrm{~F}$. Supp. 760, 769-70 (D. Colo.), affd, 402 F.2d 394 (10th Cir. 1968), cert. denied, 403 U.S. 955 (1971) (affirming conviction over defendant's claim that still photography during trial and televising of jury's return and judge's reading of verdict denied him due process).

66. Injury to inditidual interests arising from the effects of recording and broadcasting on the personal sensitivities of participants in public events is not sufficient by itself to justify restricting the rights of the press. In an analogous area, ordinary tort remedies for invasion of privacy or defamation are unavailable to public officials or public figures, see Gertz $v$. Robert Welch, Inc., 418 L.S. 323, 342-46 (1974); Curtis Publishing Co. v. Butts, 388 U.S. 130 (1967); New York Times Co. Y. Sullivan, 376 U.S. 254 (1964), unless information that is talse is disseminated with knowledge or reckless disregard of its falsity, see Gertz v. Robert Welch, Inc., supra at $334 \&$ n.6. Thus, participants in public events usually have no legal recourse for psychological injury resulting from press coverage. These limitations on the tort remedies are imposed precisely because the first amendment favors the recording and dissemination of reports about public events over the protection of personal sensitivities. 
ings to the citizenry. Once an impediment to this protected flow of information is shown, the restrictive rules can be justified only by a clear showing that the potential harm to the operation of the legislative process outweighs the rules' encroachment on first amendment interests.

Reporters may record information concerning a public event by various methods, including using their memories, making handwritten notes and sketches, and recording sounds or visual images with a tape recorder, a still photographic camera, or a motion picture or television camera. It can be argued that the dissemination of substantially equivalent information about legislative proceedings to the public is possible under rules that restrict tape recording and broadcasting, since alternative methods of recording are available. ${ }^{67}$ For example, print and broadcast reports could be organized from handwritten notes or from the verbatim transcripts of proceedings and other official reports produced by many legislatures. These alternatives, however, are not equivalent in their effectiveness. Rules that limit the press to recording legislative proceedings by such methods produce a significant decrease in the quality of the information ultimately received by the public, in terms of its accuracy and its timeliness. The extent of this restriction on the right of the press to gather news and on the free flow of public information must be determined, if only roughly, in order to weigh it against the arguably justifying governmental interest.

Each method of recording has unique capabilities and limitations, and the uses to which each method may be put by the print media and the broadcast media differ as well. ${ }^{68}$ Thus, specific restrictions, viewed in the light of their impact on different media,

67. The existence of alternative methods of recording is one ground on which several state courts have upheld rules against recording and broadcasting legislative proceedings. See 1590 Broadcasting Corp. v. Public Util. Comm'n, 113 N.H. 258, 260, 306 A.2d 49, 51 (1973); $c f$. Sigma Delta Chi v. Spèaker, Md. House of Delegates, 270 Md. 1, 6-8, 310 A.2d 156, 159-61 (1973); Educational Broadcasting Sys., Inc. v. Ronan, 68 Misc. 2d 776, 779, 328 N.Y.S.2d 107, 109-10 (Sup. Ct. 1972). These cases, however, reflect a narrow view of the press's right to record that is inconsistent with the protection of the right to gather news that has been accorded by other courts. See text and notes at notes 83-86 infra.

68. Although a newspaper, for example, could use sound-on-film cameras to record events, it could not utilize much of the increased accuracy that they would provide. The organizer (writer) of a newspaper report could view the films of an event repeatedly-giving him some advantage over a one time viewer-but he still must reduce the event to printed words because that is the form in which his medium disseminates reports. The newspaper therefore confines itself to recording events in ways most usable in printed reports, and the marginal increase in accuracy of sound-on-film cameras does not justify their cost. 
produce qualitative differences in the information disseminated and received by the public.

Prohibition of tape recording handicaps print media reporters' efforts to provide full, accurate, and timely accounts of legislative proceedings. ${ }^{69}$ A reporter taking handwritten notes cannot record lengthy verbatim quotes as easily or effectively as with a tape recorder, ${ }^{70}$ and the accuracy of reports organized from handwritten notes cannot be verified as they can by comparisons to original tape recordings. Although many legislative bodies provide verbatim transcripts or summaries of proceedings, a period of time must elapse in their transcription, printing, and distribution. ${ }^{71}$ Thus, even where such records are available, tape recording enables print reporters to publish full and accurate reports while legislative events are still fresh news, rather than a day or a week later. The importance of the print media's ability to provide the public with full, accurate, and timely accounts is underscored by the fact that broadcast coverage, because of inherent time limitations, may be unable to provide more than summaries of some events..$^{72}$

The prohibition of tape recording also has a negative impact on broadcast reporting, for similar reasons: a completely accurate and

69. See Sigma Delta Chi v. Speaker, Md. House of Delegates, 270 Md. 1, 6, 310 A.2d 156, 159 (1973).

70. See generally Wrather-Alvarez Broadcasting, Inc. x. Hewicker, 147 Cal. App. 2d 509, 511,305 P.2d 236, 237 (1957) (plaintiff was a television journalist).

71. See id.

72. Although a newspaper can adjust the amount of information it disseminates to some extent by adding or subtracting pages, the amount of information broadcast media may disseminate is strictly defined in terms of hours, minutes, and seconds. See Miami Herald Publishing Co. v. Tornillo, 418 U.S. 241, 256-57 \& n.22 (1974); E. Epsteis, News From Nowhere 78-91 (1973); Project, Mass Media and the Fïst Amendment in a Free Society, 60 Geo. L.J. 867, 937 (1972) [hereinafter cited as Project]. Because of this limitation, the broadcast media must use a combination of films and tapes of events, as well as summary reports initially recorded in the same manner as newspaper reports. Events of great interest are broadcast in their entirety. Less important events are reported through combinations of taped or filmed reports and summary reports. See E. EPSTEIN, supra at 152-54: Hearings on the Legislative Reorganization Act of 1970 Before the Special Subcomm. on Legislative Reorganization of the House Comm. on Rules, 91 st Cong., lst Sess., at 64 (1970) [hereinafter cited as 1970 Hearings].

Thus, as one well-known television news reporter has written:

The news magazines, newspapers, and television news-contrary to some popular belief-do not compete with each other in an editorial sense. . . . [T]eler ision's unique ability to carry the viewer to the scene of the story ... gives [the] afternoon news [paper] story another set of dimensions: the dimensions of sight and sound. . . .

....

The other side of the coin is the limitation of the daily evening [telerision news] round-up program .... These daily newscasts can only supplement newspapers. . . . The newspaper, and the magazine, remain the source of detailed, in-depth, permanent record....

Cronkite, Telerision and the Neuts, in The EIGHTH ART 237 (1962). 
timely report of public proceedings is made more difficult to produce. In addition, prohibition of tape recording prevents broadcast media, especially radio, from broadcasting tapes of legislative events themselves. Such broadcasts improve the quality of the information that the public receives by removing the intermediary party-the writer-who in print reporting must stand between the event and the public, and by permitting the listener to hear nuances of tone and inflection that are lost in a printed record. ${ }^{73}$ Moreover, live radio broadcasts permit instantaneous reporting, without the lapse of time needed by print media to organize and disseminate reports after an initial recording is made. ${ }^{74}$ Thus, just as prohibitions against tape recording impede the ability of the print media to provide accurate reports within a short time, the prohibition of broadcasting also impedes the unique ability of radio to report legislative proceedings with even greater celerity.

The impact upon the public of filmed or live television coverage is unequalled by the other forms of news reporting. The public relies more on television news than on other media, both for general news coverage ${ }^{75}$ and for coverage of governmental and political affairs, ${ }^{76}$ and it places more trust in the accuracy of television news than in the accuracy of news reported by other media. ${ }^{77}$ Television shares the advantages of radio in the timeliness of reports it is able to disseminate. In addition, video coverage enhances the quality of the reports disseminated, not merely by adding visual nuances to the viewers' perception of an event, ${ }^{78}$ but by involving them in the event through the combination of sight and sound as if they were attending it in person. ${ }^{79}$ Television broadcasting, by making legislative events more immediate and accessible to the public, can increase the public's interest in and knowledge of the legislative process as no other method of recording and dissemination can. ${ }^{80}$

73. When newspapers print verbatim transcripts of legislative proceedings, they too provide unintermediated coverage, but the nuances of speech are still lost.

74. Cf. Associated Press v. KVOS, 80 F.2d 575, 577 (9th Cir. 1935).

75. Project, supra note 72, at 936.

76. S. REP. No. 1275, 93d Cong., 2d Sess. 69 (1974).

77. Project, supra note 72, at 936.

78. Such nuances often affect meaning as well as reveal character, as appellate courts universally recognize in their deference to trial courts' findings of fact that are based on testimony. See, e.g., Madrid v. Mine Safety Appliance Co., 486 F.2d 856, 858 n.1 (10th Cir. 1973); Moskowitz v. Peariso, 458 F.2d 240, 245 (6th Cir. 1972); Dyer v. McDougall, 201 F.2d 265, 268-69 (2d Cir. 1952).

79. See Project, supra note 72, at 937; Cronkite, supra note 72, at 237-38.

80. A study of the effects of telecasts of the Florida legislature found that state high school students' general interest in the political system had increased, as well as the level of their discussion about politics, their related reading of state legislative news in the newspa- 
Thus, the effectiveness of the reporting process and the quality of the information disseminated to the public are diminished by restrictions on the use of certain recording methods to report public legislative proceedings. Bans on tape recording and on radio and television broadcasting reduce the accuracy and timeliness of the reports the press media are able to disseminate and preclude the unique involvement of the public in the workings of government that live and filmed television reports can provide. This impeding of the right of the press and of the free flow of information can be validated only by a showing that tape recording and broadcasting significantly endanger the smooth operation of the legislative process.

\section{The Constitutionality of Restrictions on the Recording and Broadcasting of Public Legislative ProceEdings}

Several state courts have rejected the first amendment challenges of members of the press to rules restricting the recording or broadcasting of legislative proceedings. ${ }^{81}$ The ground for these decisions, ${ }^{82}$ however, has been that members of the press have no

pers, their political knowledge, and their perceptions of legislators' trustworthiness and openness. Atkin \& Greenberg, Public Television and Political Socialization, in 1974 Hearings, supra note 4, at App. 552-53. Justice Harlan recognized the beneficial effects of television broadcasting of public events in Estes, when he said: "Many trials are newsworthy, and televising them might well provide the most accurate and comprehensive means of conveying their content to the public. Furthermore, television is capable of performing an educational function by acquainting the public with the judicial process in action." Estes $v$. Texas, 381 U.S. 532, 589 (1965) (Harlan, J., concurring).

81. Sigma Delta Chi v. Speaker, Md. House of Delegates, 270 .Id. 1, 310 A.2d 156 (1973) (no right to tape record public state legislative proceedings): 1590 Broadcasting Corp. v. Public Util. Comm'n, 113 N.H. 258, 306 A.2d 49 (N.H. 1973) (no right to tape record public utilities commission rate hearing): Educational Broadcasting Sys., Inc. v. Ronan, 68 Misc. 2d 776, 328 N.Y.S.2d 107 (Sup. Ct. 1972) (no right to televise public utilities commission rate hearing); Davidson v. Common Council, 40 Misc. 2d 1053, 244 N.Y.S.2d 385 (Sup. Ct. 1963) (no right to tape record city council meetings). But see cases cited note 86 infra. Although 1590 and Ronan involved regulatory commissions considering public utility rate increases, such hearings do not differ functionally from legislative proceedings. See note 97 infra. See generally Bennett, Broadcast Coterage of Administratize Proceedings, 67 Nw. L.L. Rev. 528 (1972).

82. The courts in two cases also suggest that they have no power to invalidate legislative rules. Educational Broadcasting Sys., Inc. v. Ronan, 68 Misc. 2d 776, 779, 328 N.Y.S.2d 107, 110 (Sup. Ct. 1972); Dav idson r. Common Council, 40 Misc. 2d 1053, 1056, 244 N.Y.S.2d 385. 388 (Sup. Ct. 1963). Even congressional rules, however, are not immune from constitutional review where they "ignore constitutional restraints or violate fundamental rights." United States r. Ballin, 144 L.S. 1, 5 (1892): see Groppi x. Leslie, 404 L.S. 496, 499507 (1972) (by implication): Consumers Lnion of L'nited States, Inc. . Periodical Correspondents Ass'n, 365 F. Supp. 18, 23-24 (D.D.C. 1973); $c$. Yellin x. Lunited States, 374 U.S. 109, 111 (1963). 
independent right to record public proceedings, at least by means other than pencil and paper, even in the absence of any showing of harm to the legislative process. ${ }^{83}$ But the right of the press to gather news has clearly been recognized by the Supreme Court, ${ }^{84}$ and limiting the press to the use of alternative, less effective methods of recording impedes the flow of public information that the constitutional protection of the freedom of the press is intended to guarantee. ${ }^{85}$ As the Estes decision indicated, such limitations may be justified when there is a substantial probability that the effects of tape recording and broadcasting would significantly endanger the fair and efficient conduct of the proceedings. Few of the prejudicial effects recognized in Estes exist in the context of legislative proceedings, however, and even those harms that do exist are not substantial enough to justify the restriction of the first amendment rights of the press. Thus, the few courts that have required that legislative rules restricting the right of the press to record and broadcast be justified by a showing of actual or impending harm to the proceedings have held the rules unconstitutional. ${ }^{86}$

\section{A. Effects of Recording and Broadcasting on Public Legislative Proceedings}

Of the three kinds of potential harm envisioned by the Estes Court-increased publicity, physical disruption, and psychological reactions to recording - only the latter two need be considered in evaluating restrictive rules of legislatures. Increased publicity resulting from the broadcast of legislative proceedings is in no way detrimental to the legislative process. Legislators, unlike jurors, may properly be influenced by the expressions of community opinion that news coverage encourages; they need not-and should not-be insulated from their constituents. The public is expected to take part in the legislative process by electing their representatives, and each election represents to some extent an expression of the judgment of the people about their representatives' actions and

83. See Sigma Delta Chi v. Speaker, Md. House of Delegates, $270 \mathrm{Md} .1,5-6,8,310 \mathrm{~A} .2 \mathrm{~d}$ 156, 158-59, 160 (1973); 1590 Broadcasting Corp. v. Public Util. Comm'n, 113 N.H. 258, 260, 306 A.2d 49, 51 (1973); Davidson v. Common Council, 40 Misc. 2d 1053, 1055-56, 244 N.Y.S.2d 385, 388 (Sup. Ct. 1963). But cf. Educational Broadcasting Sys., Inc. v. Ronan, 68 Misc. 2d 776, 778, 328 N.Y.S.2d 107, 109 (Sup. Ct. 1972); note 82 supra.

84. See text and notes at notes 12-16 supra.

85. See text and notes at notes 7-11 supra.

86. Nevens r. City of Chino, 233 Cal. App. 2d 775, 44 Cal. Rptr. 50 (Dist. Ct. App. 1965) (right to tape record city council meeting); Asbury Park Press, Inc. v. City of Asbury Park, 7 P \& F Radio Reg. If 160, at 2062 (...J. Super. Ct., Ch. Div., Sept. 24, 195I) (right to radio-broadcast public hearing on proposed municipal luxury tax). 
positions while in office. The Supreme Court has emphasized that news coverage of governmental issues, debates, and decisions is essential if the public is to perform its role in the electoral process wisely and effectively. ${ }^{87}$ Increasing the quality, accuracy, or amount of legislative news coverage, given this constitutional scheme, can only benefit the legislature and its constituency. ${ }^{88}$ The criminal trial analogy, insofar as it involves the effects of publicity, is inapposite.

The danger of physical disruption from recording mechanisms, however, exists for legislative proceedings as well as for criminal trials. As Estes implies, ${ }^{89}$ this danger by itself could not justify the prohibition of potentially disruptive means of recording, because the press (and specifically the broadcast media) are capable of operating without the chaos sometimes associated with them. ${ }^{90}$ Legislators certainly would be hampered by having to contend with the commotion of roaming camera operators and other personnel, blinding lights, clumsy cables, and other physical distractions. Many legislative chambers, however, have raised press galleries where equipment can be installed to minimize physical distractions; where quarters are cramped, pooling of coverage is possible. ${ }^{91}$ Audio signals can often be supplied by microphones that already feed the legislative chamber's own sound system. ${ }^{92}$ Some legislative chambers have enough natural light to permit filming and telecast-

87. See, e.g., Cox Broadcasting Corp. 1. Cohn, 95 S. Ct. 1029, 1044, 1046 (1975): Time, Inc. 、. Hill, 385 U.S. $374,388-89$ (1967); Mills r. Alabama, 384 U.S. 214, 218-19 (1966); New York Times Co. 1. Sullivan, 376 L'.S. 254, 269-70 (1964): Grosjean v. American Press, 297 L.S. 233, 250 (1936). See also Branzburg 1. Hayes, 408 L.S. 665, $726-27$ \& n.3 (1972) (Stewart, J., dissenting): Comment, Privacy in the First Amendment, 82 Yale L.J. 1462, $1464(1973)$.

This participatory function involves a more active role of the public than the watchdog function that underlies the requirement of public trials. See note 42 supra. In addition, publicizing legislative proceedings serves a legitimate educative function that has been rejected in the context of criminal trials. See Estes s. Texas, 381 U.S. 532, 575-76 (1964) (Warren, C.J., concurring); Delaney v. United States, 199 F.2d 107, 115 (1st Cir. 1952); Application of United States Senate Select Comm. on Presidential Campaign. Activities, 361 F. Supp. 1270, $1281-82$ (D.D.C. 1973); Lnited States v. Hintz, 193 F. Supp. 325, 331 (N.D. Ill. 1961): Yesawich, Televising and Broadcasting Trials, 37 CoRNELL L.Q. 701, 702-03 (1952).

88. When there are compelling reasons to prevent dissemination of information about legislative proceedings, legislative bodies may achiese that purpose by meeting in closed or executive session. See note 1 supra. But when the proceedings are open to public and press, limitations on tape recording and broadcasting cannot be justified as means of reducing publicity.

89. See note 48 supra.

90. See, e.g., Educational Broadcasting Sys., Inc. v. Ronan, 68 Misc. 2d 776, 778, 328 N.Y.S.2d 107, 109 (Sup. Ct. 1972).

91. 1970 Hearings, supra note 72 , at $\mathbf{5 3}$.

92. Id. at $31,56,82$. 
ing without any supplemental lighting, ${ }^{93}$ especially with the continuing development of more sensitive video equipment. ${ }^{94}$ Thus legislative rules aimed at preventing physical disruption by recording equipment or personnel can be much more narrowly drawn than in the form of a flat prohibition, requiring instead that the least disruptive methods be used ${ }^{95}$ Moreover, physical interference is readily ascertainable, so that a presumption of its occurrence need never be substituted for proof.

Recording and broadcasting may have psychological effects on legislators as well as on trial participants. Hence, although legislators' personal feelings about recording cannot be taken into account, ${ }^{96}$ changes in their behavior that are detrimental to the legislative process may be. ${ }^{97}$ Proponents of rules prohibiting legislative recordings argue that the legislators' knowledge that recording or broadcasting is taking place would both distract the legislators and inspire them to "grandstand."98 The distraction, it is said, would result from the legislators' anxiety about how they sound or look. ${ }^{99}$ The "grandstanding" argument implicitly assumes

93. S. Mickelson, The Electric Mirror 182 (1972).

94. \. Minow, J. Martin \& L. Mrtchell, Presidential Television 124 (1973) [hereinafter cited as Presidential Television]; Joint Comm. on Congressional Operations, Broadcasting House and Senate Proceedings, S. Rep. No. 1275, 93d Cong., 2d Sess. 50-51 (1974) [hereinafter cited as Congressional Broadcasting Report].

95. The Legislative Reorganization Act of 1970, authorizing congressional committees to allow broadcast coverage of their hearings, takes reasonable precautions to prevent physical disruption of proceedings. It limits the permissible number and position of television and still cameras, requires that hearing participants' sight lines be kept unobstructed, and allows the installation of only enough additional lighting to provide the minimum level required by the current state of television technology. Legislative Reorganization Act of 1970, Pub. L. No. 91-510, \$116(f)(3)-(13), 84 Stat. 1154-55.

Similarly, the Administrative Conference of the United States has adopted a recommendation that federal administrative agencies permit broadcast coverage of some proceedings, but with the proviso that:

Audio visual coverage should be conducted with minimal physical intrusion on the normal course of the proceeding. Agencies should impose reasonable restrictions on lighting, multiple microphones and other possible sources of disruption.

Recommendation 32, Administrative Conference of the United States, $1971-72$ Report 78 (1972).

96. See note 66 supra.

97. Even these behavioral effects are unlikely to have as great an impact on the proceedings or to threaten as fundamental a right as in the trial context. Because of the different interests involved, the Administrative Conference specifically excluded adjudicatory hearings from its recommendations for broadcast coverage of federal administrative agency proceedings. Recommendation 32, Administrative Conference of the United States, 1971-72 REPORT 77 (1972). See Bennett, supra note 81, at 548-52.

98. See, e.g., S. Mickelson, supra note 93, at 123; Congressional Broadcasting Report, sup)a note 94, at 19; 1970 Hearings, supra note 72, at 50-51; 116 ConG. Rec. 24971 (1970) (remarks of Representative Dennis); 65 HaRv. L. REv. 1258, 1260 (1952).

99. S. MICKELSON, supra note 93; 1970 Hearings, supra note 72, at 50. 
that legislators meeting in public session speak or act differently in the presence of some forms of recording than in their absence. The premise, rarely stated clearly, may be either that legislators would say what they think their constituents want to hear rather than what the legislators themselves think is best, ${ }^{100}$ that demagogic legislators will use recorded or broadcast legislative proceedings to stir the public's passions, ${ }^{101}$ or that legislators will vie with each other for recorded or broadcast press coverage with an eye toward future political campaigns. ${ }^{102}$ The fear, then, is that recording and broadcasting will affect the quality and the length of legislative debate and decision making.

The likelihood of distraction of legislators due to anxiety or nervousness about being recorded or broadcast is considerably less than in the case of jurors. Unlike jurors, legislators are already (and voluntarily) public figures; they are accustomed to speaking and acting in proceedings with knowledge that their words and actions will receive widespread attention, and many have had experience with sound and video recording. Even if this were not so, the repeated exposure of legislators to these recording methods over the course of several legislative sessions would give them a greater opportunity to become accustomed to being recorded or broadcast than a juror or criminal trial witness would have.

Similarly, the likely incidence and detrimental effects of "grandstanding," whatever its form, are not great. Legislators who wish to conform their positions to those that they think a majority of their constituents support are likely to do so with or without recording. Those who do not wish to do so but feel that they must as their positions become more widely publicized are reacting to electoral pressures; as noted before, such pressures are an inherent and proper part of the legislative process. The essence of such legislators' complaints is that the public would not be as ignorant of their positions as before.

Demagogic legislators exist and sometimes engage in improper conduct during legislative sessions, and it may be argued that giving such conduct more widespread press coverage might encourage its growth. Thoughtful commentators have suggested, however, that the opposite effect would result; as the demagogic

100. More specifically, the danger has been characterized as the likelihood that necessary compromise would be inhibited. Congresstonal BroAdCASTing REPORT, supra note 94, at 18-19.

101. Cf. 116 CoNG. Rec. $24971-72$ (1970) (exchange between Representatives Dennis and Harrey).

102. Congressional Broadcasting Report, supra note 94, at 19. 
legislator's constituents become more aware of his objectionable behavior, his electoral position would erode. ${ }^{103}$ This argument rests on faith in the ability of the electorate to judge its own legislators by appropriate standards, an assumption that is difficult to prove or disprove but one that underlies both the system of democratic elections and the Supreme Court's view that protection of the freedom of the press is essential to the proper workings of government. ${ }^{104}$

Whether incumbent legislators would compete for coverage to gain electoral advantage is also uncertain, as is the harm that would be caused if they did. If the concern is that legislative time will be wasted on speeches that would not have been made if they had not been recorded or broadcast, limits on the length and subject matter of speeches imposed by the presiding officer ${ }^{105}$ or by specific rules would deal with the problem sufficiently, more directly, and less restrictively. If the concern is that incumbents, by taking advantage of free press coverage, will increase their chances of reelection against challengers, the combined effects of closer control over electioneering by the chair or through specific rules and the recognition of that advantage by the electorate ${ }^{106}$ would similarly minimize the danger more directly and less restrictively.

Several other dangers of recording and broadcasting that have been raised in courts and by legislators rest on grounds that are improperly considered in evaluating a first amendment claim. The arguments are that broadcasters would distort their coverage through misleading editing, ${ }^{107}$ that commercial sponsorship of legislative broadcasts should not be permitted, ${ }^{108}$ that the public

103. See Presidential Television, supra note 94, at 107 (attributing the decline in Senator Joseph McCarthy's support to the viewing by a wide audience of his televised testimony during Senate committee hearings in 1954); of. 116 CoNG. REc. 24972 (1970).

104. See text and note at note 87 supra.

105. See, e.g., Senate Comm. on Rules and Administration, Standing Rules of the Senate, S. Doc. No. 1, 93d Cong., 1st Sess. 10-11, 21-22, 24-25 (1973) (Rules VIII (3), XIX (1)-(6), XXII (2), indicating possible limits on subject matter and length of debate).

106. Some commentators have suggested that if the problem arose, it might be self-correcting, since "the ability to speak in congressional debate is an inherent advantage of incumbency; public resentment would soon cure abuses of televised debates for electioneering." Presidential Television, supra note 94, at 213-14 n.67.

107. See, e.g., 1970 Hearings, supra note 72, at 34-36, 50, 54.

108. Legislative Reorganization Act of 1970, Pub. L. No. 91-510, § 116(f)(1), 84 Stat. 1154, forbids commercial sponsorship of live committee broadcasts. The court in Davidson v. Common Council, 40 Misc. 2d 1053, 244 N.Y.S.2d 385 (Sup. Ct. 1963) characterized the danger of commercial sponsorship as allowing the legislative process to be "turned into a show where portions of tape-recorded material can be played on radio or television between the trumpeters of modern merchandising expounding the virtues of tooth paste, cigarettes, soap powder or the mellowness of a new beer." Id. at 1055, 244 N.Y.S.2d at 388. 
would view the broadcasts as "entertainment" rather than "education"109 and that broadcasters would exert increasing control over the timing and format of proceedings. ${ }^{110}$ The potential for distortion in reporting, always present, has never justified prior restraints. The fear is only that editorial judgment, a prerogative clearly protected by the first amendment, ${ }^{111}$ will be exercised in an objectionable manner. Similarly, the commercial nature of a medium does not affect its claim to first amendment protection. ${ }^{112}$ Moreover, in view of the high costs of broadcasting, to forbid sponsorship might well be to preclude broadcasting altogether. ${ }^{113}$ The next argument against recording and broadcasting, based on the elusive distinction between publications that "entertain" and those that "educate," is irrelevant in light of the Supreme Court's holdings that both kinds of publications are within the ambit of the first amendment. ${ }^{114}$ In addition, at least one study shows that broadcast coverage of legislative proceedings can have significant educational value. ${ }^{115}$ Finally, the timing and format of legislative proceedings are firmly within the legislature's control;116 although either broadcasters or the public might suggest changes to facilitate broadcast reporting of the proceedings, ${ }^{117}$ the legislature could properly decline to make them.

The potential dangers posed to legislative proceedings by recording and broadcasting-especially the psychological effects-are difficult to prove or disprove. ${ }^{118}$ Reasons for expecting that such dangers are less likely to exist in legislative proceedings than in crimi-

109. See Davidson v. Common Council, 40 Misc. 2d 1053, 1055, 244 N.Y.S.2d 385, 388 (Sup. Ct. 1963).

110. Presidential Television, supra note 94, at 123.

111. See text and notes at notes 10-11 supra.

112. Smith v. California, 361 U.S. 147, 150 (1959). See, e.g., Time, Inc. v. Hill, 385 U.S. 374, 397 (1967); Near v. Minnesota ex rel. Olson, 283 U.S. 697, 720 (1931).

113. It has been estimated that uninterrupted broadcasts of the House Judiciary Committee's impeachment hearings cost each commercial network $\$ 1,000,000$ per day in lost advertising revenues. BroAdCASTING, Aug. 5, 1974, at 18.

114. See, e.g., Joseph Burstyn, Inc. v. Wilson, 343 U.S. 495, 501 (1952).

115. Atkin \& Greenberg, supra note 80, at App. 482-566.

116. See, e.g., Asbury Park Press, Inc. v. City of Asbury Park, 7 P \& F Radio Rec. $\$ 160$ (N.J. Super. Ct., Ch. Div., Sept. 24, 1951).

117. Some writers, concerned about the imbalance between presidential and congressional power and access to channels of communication to the public, have suggested that Congress allow television broadcasts of "specially scheduled prime-time evening sessions at which the most important matters before it each term are discussed, debated, and then voted upon." Presidential Television, supra note 94, at 122.

118. As the Estes Court stated in concluding that prejudice should be presumed in the criminal trial context, “one cannot put his finger on [television's] specific mischief and prove with particularity wherein he was prejudiced." Estes v. Texas, 381 U.S. 532, 544 (1965). 
nal trials and are less likely to be detrimental when they do exist have been discussed above. Actual experience with recording and broadcasting further supports the conclusion that they do not harm public legislative proceedings.

Many state and local legislative bodies currently permit recording and broadcasting of their public proceedings, ${ }^{119}$ as do many other nations' highest legislative bodies. ${ }^{120}$ This fact is relevant to the ultimate legal judgment, for the Court in Estes gave weight to the fact that forty-eight states prohibited courtroom televising, ${ }^{121}$ and the Fifth Circuit in the Columbia Broadcasting case emphasized the fact that no other court prohibited courtroom sketching. ${ }^{122}$ Although a simple comparison of the number of bodies that permit recording and broadcasting with those that prohibit the activities cannot be determinative of the constitutional issue, the fact that a substantial number do permit such coverage supports an inference that it does not endanger the proceedings.

Hearings before the Joint Committee on Congressional Operations on the issue of whether Congress should permit broadcast coverage of its floor proceedings ${ }^{123}$ provide more direct evidence that recording and broadcasting do not threaten legislative proceedings. Studies presented to the Committee on the effect of telecasting sessions of the Florida and Connecticut state legislatures concluded that psychological discomfort and behavioral changes

119. In 1965 the National Association of Broadcasters reported that nineteen states permitted daily radio and television coverage of their legislatures. 1970 Hearings, supra note 72 , at 53. It appears that that number has increased since 1965. See id. at 53-56; 1974 Hearings, supra note 4, at App. 470-71, 949-50; Congressional Research Serv., Joint Comm. on Congressional Operations, 93d Cong., 2d Sess., Congress and Mass Communications: An Institutional Perspective 47 (Comm. Print 1974) [hereinafter cited as Mass Communications]. Cf. note 4 supra.

120. Of fifty national legislative bodies surveyed in 1968, twenty-nine allowed radio coverage and twenty-one allowed telecasts. 1974 Hearings, supra note 4, App. at 918. Among them are Australia, Austria, Denmark, Finland, Holland, Japan, New Zealand, Norway, and West Germany. A number of Canadian provinces also allow broadcasting. Id. at 918-24; S. Mickelson, supra note 93 , at $182-83$. The United Nations also allows broadcasts of its proceedings. 1974 Hearings, supra note 4, at App. 919-20.

121. Estes v. Texas, 381 U.S. 532, 540 (1965). See note 30 supra.

122. United States v. Columbia Broadcasting Sys., Inc., 497 F.2d 102, 106 (5th Cir. 1974). See note 55 supra.

123. Recording and broadcasting House and Senate floor proceedings has never been allowed except for ceremonial occasions such as State of the Union addresses. See generally E. Chester, Radio, Television and American Politics 163-64 (1969); S. Mickelson, supra note 93, at 177-78; Presidential Television, supra note 94, at 106-07; Mass Communications, supra note 119 , at 24-26. Shortly before the resignation of President Nixon, however, the House of Representatives adopted a resolution to permit broadcasts of impeachment proceedings. H.R. Res. 802, 93d Cong., 2d Sess. (1974); 120 Cong. Rec. H7851-54 (daily ed. Aug. 7, 1974). 
in legislators detrimental to proceedings were minimal and short-lived. ${ }^{124}$ Both studies endorsed expansion of such coverage. ${ }^{125}$ Witnesses also testified as to improvements in legislative decorum, attendance, and efficiency after broadcasts of public proceedings began. ${ }^{126}$ On the basis of these hearings, the Joint Committee recommended that, in addition to the broadcast coverage of committees already permitted, ${ }^{127}$ broadcast coverage of congressional floor proceedings be authorized for a one year trial period. ${ }^{128}$

\section{B. Failure of the Asserted Justification for the First Amendment Restriction}

Rules that prohibit tape recording or broadcasting of public legislative proceedings, as discussed above, produce a significant diminution in the effectiveness of the reporting process and in the quality of the information about the proceedings that is dissemi-

124. See 1974 Hearings, supra note 4, at App. 645-60, 734-54.

125. The findings are summarized in the Joint Committee's Report:

The adverse results [of televising legislatures] often thought to be most damaging to proper decorum-"grandstanding" for the cameras-were either not in evidence or disappeared quickly, as those so inclined were subjected to ribbing from their colleagues. Rather than finding that they could not "be themselves" and "keep their minds on their business," particularly in Florida, where the proceedings were recorded on videotape in their entirety, Members of both Houses soon ignored the camera's presence and got "back to business as usual."

Congressional Broadcasting Report, supra note 94, at 52. See 1974 Hearings, supra note 4, at App. 653-60, 748-49.

126. Congressional Broadcasting Report, supra note 94, at 52; 1974 Hearings, supra note 4, App. at 751. See 1970 Hearings, supra note 72, at 31-32, 54, 56.

127. Prior to passage of the Legislative Reorganization Act of 1970, Pub. L. No. 91-510, $\$ 116,84$ Stat. 1153-55, only Senate committees could broadcast their meetings. Each committee of the House of Representatives now may also decide whether to permit broadcast coverage of its proceedings.

Significantly, when witnesses subpoenaed to testify before televised congressional hearings have objected, the courts have declined to follow the courtroom analogy, holding that a committee is not an incompetent tribunal simply because it is being televised. Hartman v. United States, 290 F.2d 460, 466-67 (9th Cir. 1961), rev'd per curiam on other grounds, 370 U.S. 724 (1962); United States v. Moran, 194 F.2d 623, 627 (2d Cir.), cert. denied, 343 U.S. 965 (1952); United States v. Hintz, 193 F. Supp. 325, 328-35 (N.D. Ill. 1961). Contra, United States v. Kleinman, 107 F. Supp. 407, 408 (D.D.C. 1952) (disapprored in Hintz). The witness's right to privacy is not violated in such cases. United States v. Hintz, 193 F. Supp. 325, 328-35 (N.D. Ill. 1961). Courts have also rejected the argument that the resultant publicity might endanger a witness's rights in subsequent criminal trials, Application of United States Senate Select Comm. on Presidential Campaign Activities, 361 F. Supp. 1270, 1280-82 (D.D.C. 1973), and they have been reluctant to delay such trials or dismiss charges because of the publicity, United States v. Mitchell, 372 F. Supp. 1239, 1260-61 (S.D.N.Y. 1973). But see Delaney v. United States, 199 F.2d 107, 109-15 (1st Cir. 1952) (distinguished in Application of United States Senate Select Comm. and Mitchell).

128. Congressional Broadcasting Report, supra note 94, at 53-56; H.R. Rep. No. 1458, 93d Cong., 2d Sess. (1974). 
nated to the public. This restriction of the freedom of the press is especially significant because of the fundamental importance of protecting the free flow of timely and accurate information about the legislative process to the citizenry. Courts considering the right of the press to record proceedings involving even less fundamental public interests have required a showing of an actual and immediate threat to the proceedings to justify restrictions on that right. ${ }^{129} \mathrm{~A}$ substantial governmental interest in preventing adverse effects on the legislative process must certainly be shown before a rule significantly impeding the right to gather news can be upheld. ${ }^{130}$

The Supreme Court in Estes recognized the overriding interest of the government in preserving the fairness of criminal trial proceedings, and found such a strong probability of prejudice in allowing trials to be tape recorded and televised that it held that such recording methods must be restricted within the courtroom. That probability of impairment of the proceedings, however, does not exist in the legislative setting. Increased publicity enhances rather than impairs legislative proceedings, and the effects of physical disruption and psychological reaction by legislators appear in actual practice to be minimal. The threat to the conduct of the legislative process posed by tape recording and broadcasting is thus virtually nonexistent, and even at most could not be considered as raising a substantial governmental interest.

Even if certain of the asserted dangers were shown to be actual and immediate, they could be prevented by other means less restrictive of the press's right to gather news than a flat prohibition of tape recording or broadcasting. ${ }^{131}$ Physical disruption may be minimized by rules such as those governing the broadcasting of congressional committee hearings. ${ }^{132}$ Psychological effects, although difficult to detect and to prevent, may also be minimized by rules and practices that are aimed directly at eliminating the specific harms foreseen.

Thus, legislative rules that absolutely prohibit tape recording and broadcasting of legislative proceedings neither further a substantial governmental interest nor protect interests that they might

129. See United States v. Columbia Broadcasting Sys., Inc., 497 F.2d 102, 106-07 (5th Cir. 1974); Dorfman v. Meiszner, 430 F.2d 558, 563 (7th Cir. 1970); text and notes at notes 53-59 supra; $c f$. note 87 supra.

130. See United States v. O'Brien, 391 U.S. 367, 377 (1968); Saxbe v. Washington Post Co., 94 S. Ct. 2811 , 2822-24 (1974) (Powell, J., dissenting).

131. See cases cited at note 130 supra.

132. See note 95 supra. 
serve by means that are least restrictive of first amendment interests. The constitutional right of the press, essential to providing the public information that guarantees the proper working of the democratic process, may therefore not be restricted.

\section{Conclusion}

The constitutional right of the press to gather news has been acknowledged by the Supreme Court but has been held to be outweighed by other substantial interests in Branzburg, Pell, and Estes. Many legislative bodies have recognized that the right of the press to record their proceedings should not be unduly restricted, and have permitted tape recording and broadcasting. Where rules prohibiting such recording methods still exist, the asserted dangers to the legislative process that they are intended to prevent fail to justify the restriction of the first amendment interests that they produce.

James D. Alt 